\title{
Estimation of dairy pastures - the need for standardisation
}

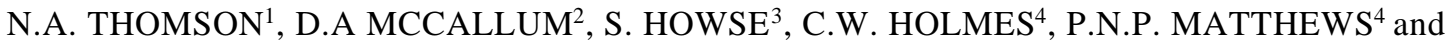 \\ C. MATTHEW ${ }^{4}$ \\ ${ }^{1}$ Dairying Research Corporation, PB 3123, Hamilton \\ ${ }^{2}$ Raine Rd, Mania, Taranaki \\ ${ }^{3}$ Livestock Improvement, PB 3016, Hamilton \\ ${ }^{4}$ Massey University, Palmerston North
}

\begin{abstract}
A study was undertaken to determine the reason for the differences in the estimation of pasture mass between dairying research centres in New Zealand and to define a common system of estimation that would overcome these differences and be able to describe the pasture situation on commercial dairy farms in different parts of New Zealand. Differences in the visual estimation of pasture between a standard observer and a local observer at the different dairying research centres in the order of $900 \mathrm{~kg} \mathrm{DM} / \mathrm{ha}$ were identified. This was attributed to a lack of regular visual calibration of persons who regularly assessed pasture, as differences between centres in the actual harvested DM yields of the visually assessed plots varied less (200-400 kg DM/ha). To achieve uniformity it is recommended that all centres measure total herbage mass (the amount of herbage above ground level) to regularly calibrate pasture assessment in dairy grazing management studies and on dairy farms. A reasonably consistent estimation of average farm cover, the ranking of paddocks $\left(\mathrm{r}^{2}>\right.$ 0.9 ) for the purposes of determining grazing order and the estimation of pre- and post-grazing herbage mass was achieved using the rising plate meter and L'Huillier \& Thomson's standard set of calibration equations published in 1988. With these recommendations, estimation of pasture will be more uniform. Standard calibration of the plate meter for the determination of rate of DM disappearance (pre-post grazing) achieved less consistency.
\end{abstract}

Keywords: herbage mass, pasture assessment, pasture height, rising plate meter, visual pasture estimation

\section{Introduction}

Regular objective assessment of pasture on a dairy farm has been recommended as a key to achieving efficient pasture utilisation and optimum levels of milksolids production (Glassey 1983). However, for many years regional differences have existed between research station personnel and dairy farm consultants in the method and level of assessment of dairy pasture. For example, the recommended residual herbage mass for grazing in spring has ranged between 1100-1300 kg DM/ha (Davie-Martin 1989), 1500-2000 kg DM/ ha (Bryant 1984) and $2200 \mathrm{~kg} \mathrm{DM} / \mathrm{ha}$ (Hainsworth \& Thomson 1997). As a result, farmers have been confused and have often questioned sound grazing management practices based on target farm covers or residual herbage mass levels owing to disparity in pasture mass estimates.

Hodgson (1979) defined the amount of pasture as herbage mass, as "the total amount of herbage per unit of ground, usually measured to ground level but otherwise above a definite reference level which must be stated". Most pasture estimations made in New Zealand are assumed to be in terms of herbage mass above ground level.

L'Huillier \& Thomson (1988) observed no difference between dairy pastures in Taranaki and the Waikato in the relationships between rising plate meter reading, pasture height and pasture probe measurements, and herbage mass cut to ground level. The main source of variation in the relationships between indirect assessment method and herbage mass was seasonal, and L'Huillier \& Thomson (1988) published a set of seasonal calibration equations for each indirect method of herbage mass assessment.

The objective of this paper is to investigate possible reasons for the apparent variation between research centres and to arrive at recommendations to standardise pasture assessment.

\section{Method}

The method of evaluation covered two stages:

Stage 1 To measure the size of any differences between the methods used at four sites, using one standard, trained person for all four sites.

Stage 2 To evaluate the pasture plate meter as a standard for assessing pasture parameters necessary for grazing management. 


\section{Stage 1}

In November 1994, a comparison was made of a standard person and local person in the visual assessment and in the cutting and harvesting of pasture for calibrating indirect assessment methods at four locations: Lincoln University Dairy Farm, Massey University Dairy Farm, Westpac Trust Agricultural Research Station (WTARS), and the Dairying Research Corporation No, 2 Dairy (DRC). The standard person, a representative of the WTARS research team, was used over all sites. As a result there was no local person used at WTARS. Thirty $0.2 \mathrm{~m}^{2}$ quadrats were paired (A and B) for similarity in herbage mass, and quadrats allocated within pairs to either the standard (A) or local (B) person (15 plots/person). All 30 quadrats were assessed visually by each person, then assessed by the standard person for height using a ruler (10 measurements/quadrat) and for compressed height using an Ellinbank rising plate meter (2 readings/ quadrat). Each person then cut their particular sub-set of 15 quadrats. The standard person first cut to $15 \mathrm{~mm}$ above soil surface then down to soil surface. The pasture samples collected by each observer were taken to their respective laboratories, washed and dried. A sub-sample of the pasture cut above $15 \mathrm{~mm}$ was dissected to grass leaf, grass stem, other grasses, clover, weeds, and dead material. Regression analyses were conducted for each component of pasture yield and the indirect assessments made.

\section{Stage 2}

The standard person and local person visually assessed the herbage mass in each paddock of the respective research dairy units (36-112 paddocks) during July and November 1995 (excluding Massey in July). Herbage mass in each paddock was visually assessed by the standard person, the local person and the rising plate meter (15 readings/paddock). Ten $0.2 \mathrm{~m}^{2}$ quadrats covering a range of herbage mass levels were visually assessed by each person and two plate meter readings/ quadrat taken. The quadrats were then cut, washed and dried by the standard person. The relationship between the indirect assessment of herbage mass and actual herbage mass ( $\mathrm{kg} \mathrm{DM} / \mathrm{ha}$ ) was determined using linear regression analyses. The visual assessments of herbage mass by each person for each paddock was "corrected" using the linear regression equation established for each person. The herbage mass of the paddock was then determined from the average of the uncorrected and corrected visual assessments made by each person. Herbage mass for each paddock was also calculated from the plate meter reading, using the regression equation established on the day from the 10 quadrats (actual) and the regression equation for the respective season (standard) published by L'Huillier \& Thomson (1988). Paddock ranking, average farm cover, and preand post-grazing herbage mass levels were determined for each of the estimates of herbage mass; the average corrected visual, actual plate and standard plate. The number of paddocks used for the exercise at each location were: Lincoln 36, Massey 36, WTARS 60 and DRC 112. At WTARS the 60 paddocks were the sum of 6 experimental farmlets (10 paddocks/farmlet) and at DRC's 8 experimental farmlets (14 paddocks/farmlet). At these locations the methods of assessing the various parameters were compared using analysis of variance.

\section{Results}

\section{Stage 1}

The difference in visual herbage mass estimation between the standard and local observer was most marked at Massey (980 kg DM/ha), smaller at Lincoln (120 kg DM/ha) and very small at DRC (Table 1). In comparison, the differences in herbage mass cut from the quadrats by the standard and local persons were small at Massey and larger at both DRC and Lincoln. Within sites, the plate meter and height measurements were similar for both the A and B quadrats, suggesting that the paired quadrats were of similar herbage mass and that differences between the standard person and local person indicate true differences in visual estimation and in calibration techniques. The total herbage mass cut from the quadrats was similar between locations. However, significant differences between sites were apparent in the relationships between cut herbage mass and plate meter reading or sward surface height. Differences between sites in the botanical composition of pasture (Table 1) are noted. The Lincoln site had less ryegrass and more other grasses (mainly Poa trivialis), whereas the DRC site had the greater ryegrass content. The WTARS and Massey farms were similar in pasture composition.

At individual sites the correlation coefficients of plate meter reading and herbage mass, and sward surface height and herbage mass were similar, which indicates either method would assess herbage mass with similar accuracy. The accuracy of visual, plate meter or height assessment of pasture (data not presented) for pasture DM above $15 \mathrm{~mm}$ and for total herbage mass was similar.

\section{Stage 2}

A summary of average farm cover (Table 2) shows a reasonable similarity between the four estimates of average farm cover in November. In July, the four estimates of average farm cover for the farmlets at DRC and WTARS differed significantly, although the 
absolute size of the differences was small. The variability was similar between the average farm cover assessed by the standard and corrected visual assessments, and between the plate meter assessments using either the actual or standard calibrations.

Regression analysis was conducted to compare the association between the herbage mass of individual paddocks determined by the corrected standard visual assessment and the rising plate meter readings calculated by either the actual or standard equations (data not presented). In all situations the actual and standard calibrations did not change the rankings of paddocks. Sixty per cent of the highest and lowest paddocks within experimental farmlets (28 farmlets) were the same irrespective of the method of herbage mass assessment. In $98 \%$ of the cases the highest or lowest paddocks assessed by the different methods did not differ by more than $200 \mathrm{~kg} \mathrm{DM} / \mathrm{ha}$.

The results presented in Table 3 show there is a general trend for the assessment methods to provide similar pre- and post-grazing herbage mass levels. However, differences between assessment methods were greater when the difference between pre- and postgrazing herbage mass was calculated.

\section{Discussion}

A standard trained observer was able to assess herbage mass over a range of sites with a reasonable degree of reliability (Table 1). Smeaton \& Winn (1981) reported variation between cutters to be significant, which is similar to the information presented in Table 1. Differences in the estimation of pasture between centres could be attributed in part to a difference in calibration methods. At Massey the local person's visual assessment of herbage mass was $980 \mathrm{~kg}$ $\mathrm{DM} /$ ha lower than the standard but the local person harvested similar total DM to the standard. This suggests the low visual estimation of herbage mass could be owing to insufficient training or calibration of the local person. Pasture
Table 1 Comparison of visual estimation of total herbage mass and cutting methods by a standard person and a local person at four locations.

\begin{tabular}{|c|c|c|c|c|}
\hline & Massey & Lincoln & DRC & WTARS \\
\hline \multicolumn{5}{|l|}{ Visual estimation } \\
\hline Standard person; A plots & 2930 & 2640 & 2850 & 3090 \\
\hline Standard person; B plots & 2970 & 2630 & 2900 & - \\
\hline Sig. A vs B plots & NS & NS & NS & \\
\hline Local person; A plots & 1940 & 2460 & - & \\
\hline Local person; B plots & 2000 & 2390 & 2880 & \\
\hline Sig. A vs B plots & NS & NS & - & - \\
\hline Sig. Standard vs local & $* * *$ & $* *$ & NS & \\
\hline \multicolumn{5}{|l|}{ Cut (kg DM/ha) } \\
\hline Standard person; A plots & 3040 & 3240 & 2650 & 3060 \\
\hline Local person; B plots & 2920 & 2830 & 3060 & - \\
\hline Sig. Standard vs. Local & NS & $* *$ & $* *$ & - \\
\hline A Plots $<15 \mathrm{~mm}$ & 860 & 900 & 790 & 690 \\
\hline A Plots $>15 \mathrm{~mm}$ & 2180 & 2340 & 1860 & 2370 \\
\hline \multicolumn{5}{|l|}{ Plate meter (mm) } \\
\hline Standard person; A plots & 104 & 68 & 75 & 107 \\
\hline Standard person; B plots & 114 & 60 & 72 & - \\
\hline$R^{2}(A)$ & 0.89 & 0.73 & 0.86 & 0.74 \\
\hline Slope \pm SE (A) & $113 \pm 11$ & $152 \pm 26$ & $177 \pm 20$ & $64 \pm 10$ \\
\hline \multicolumn{5}{|l|}{ Sward surface height (mm) } \\
\hline Standard person; A plots & 153 & 85 & 117 & 157 \\
\hline Standard person; B plots & 157 & 83 & 121 & - \\
\hline$R^{2}(A)$ & 0.84 & 0.52 & 0.85 & 0.63 \\
\hline Slope \pm SE $(A)$ & $164 \pm 20$ & $272 \pm 72$ & $167 \pm 20$ & $89 \pm 19$ \\
\hline Composition of A plots above $15 \mathrm{~mm}$ & & & & “ \\
\hline Ryegrass leaf\% & 26 & 17 & 42 & 25 \\
\hline Ryegrass stem\% & 28 & 26 & 29 & 32 \\
\hline Total ryegrass & 54 & 43 & 71 & 57 \\
\hline Clover\% & 9 & 2 & 2 & 4 \\
\hline Other grasses & 13 & 27 & 3 & 16 \\
\hline Weeds\% & 1 & 3 & 4 & 3 \\
\hline Dead\% & 24 & 25 & 20 & 20 \\
\hline
\end{tabular}

Significance: NS not significant, ${ }^{* *} \mathrm{P}<0.01$.

Table 2 Average farm cover ( $\mathrm{kg} \mathrm{DM} / \mathrm{ha}$ ) recorded at three sites in July and four in November.

\begin{tabular}{|c|c|c|c|c|}
\hline & $\begin{array}{c}\text { Massey } \\
(\mathrm{kg} \mathrm{DM} / \mathrm{ha})\end{array}$ & $\begin{array}{c}\text { Lincoln } \\
\text { (kg DM/ha) }\end{array}$ & $\begin{array}{c}\text { DRC } \\
\text { (kg DM/ha) }\end{array}$ & $\begin{array}{c}\text { WTARS } \\
\text { (kg DM/ha) }\end{array}$ \\
\hline \multicolumn{5}{|l|}{ July 1995} \\
\hline Uncorrected visual & & 2450 & $2060 A^{*}$ & $2170 \mathrm{~A}$ \\
\hline Corrected Visual & - & 2620 & $1890 \mathrm{~B}$ & $2080 A B$ \\
\hline Plate actual & - & 2180 & $1690 \mathrm{C}$ & $1880 \mathrm{~B}$ \\
\hline Plate Standard & - & 1670 & $1970 A B$ & $1620 \mathrm{C}$ \\
\hline \multicolumn{5}{|l|}{ November 1995} \\
\hline Uncorrected visual & 2680 & 2670 & $2620 a$ & $2670 \mathrm{a}$ \\
\hline Corrected visual & 2680 & 2290 & $2500 \mathrm{a}$ & $2740 \mathrm{a}$ \\
\hline Plate actual & 2420 & 2060 & $2370 \mathrm{~b}$ & $2720 \mathrm{a}$ \\
\hline Plate Standard & 2520 & 2370 & $2570 \mathrm{a}$ & $2640 \mathrm{a}$ \\
\hline
\end{tabular}


assessment personnel at WTARS and DRC have always been calibrated weekly, which may explain the similarity of the two observers at DRC. A difference in the amount of pasture harvested from the quadrats was recorded between the standard person and the local person at Lincoln and DRC, indicating differences between sites in cutting, washing or drying techniques and highlighting a need for greater standardisation.

No difference was found in the accuracy of assessment between harvesting the quadrats at $15 \mathrm{~mm}$ or at ground level. Therefore there was little justification to change the standard recommendation of assessing herbage mass to ground level. Pasture height assessed herbage mass with similar accuracy to the plate meter, but was more laborious.

The significant differences in relationships between height, plate meter reading and herbage mass between sites suggests that a standard equation to describe herbage mass of dairy pastures would not be appropriate. This argument, however, is not entirely supported by the results of the whole farm studies presented in Tables 2 and 3. The difference in average farm cover between uncorrected and corrected visual estimates is as great as the difference between actual and standard calculations of herbage mass using the plate meter. If we assume that the corrected visual estimate by the trained standard observer is the best estimate of herbage mass, then the results presented in Table 3 show the standard plate gave a reasonable estimate of average farm cover. Two estimates were low, but the other five were within $200 \mathrm{~kg} \mathrm{DM} / \mathrm{ha}$ of the corrected visual assessment. Considering the errors associated with the estimation of herbage mass, the standard plate is acceptable. Only 15 plate meter estimates per paddock were used in the study, which would be insufficient considering a standard error (SE) estimate of 350-450 kg DM/ha (L'Huillier \& Thomson, 1988). From the SE of pasture assessment, 50-80 estimates per paddock should be taken to obtain the most accurate estimate of herbage mass. The information that $98 \%$ of paddocks were ranked by either the corrected visual or standard plate meter assessments, within 200 $\mathrm{kg} \mathrm{DM} / \mathrm{ha}$, supports the use of the plate meter and the L'Huillier \& Thomson (1988) equations for on-farm assessment of dairy pasture.

The difference between pre- and post-grazing herbage mass is often used to calculate the amount of DM consumed or intake. However, when considering the variability of the amount of DM consumed arising from the different methods (Table 3), the use of this grazing parameter must be treated with caution. The most reliable on-farm estimations of pasture are average farm cover and paddock ranking to determine grazing order.

\section{Conclusions}

From the assumption that there is a real need for a more standardised method of pasture estimation, the following recommendations are made:

- Pastures are assessed in terms of total herbage mass above ground level, which should be assessed by cutting quadrats to ground level, collecting all herbage, washing thoroughly to remove all soil, and drying at $80-90^{\circ} \mathrm{C}$ to constant weight.

- Measuring pasture height, or estimating pasture mass above a higher base than ground level, does not improve the accuracy of pasture estimation.

- Trained observers without calibration, and the plate meter using a standard calibration equation, assess herbage mass with similar accuracy.

- For on-farm estimation of average farm cover the rising plate meter should be used in conjunction with the seasonal equations of L'Huillier \& Thomson (1988). 
- At least 50 plate meter readings per paddock should be taken to determine average farm cover, to rank paddocks for grazing order and to determine herbage mass before and after grazing.

With the adoption of these recommendations, research dairies, university farms, dairy farm consultants and dairy farmers should be able to communicate dairy grazing management from a more common base.

\section{ACKNOWLEDGEMENTS}

The technical assistance of Andrea Pearson and Robyn Hainsworth; WTARS, Wally Carter; DRC, Steve Kirsipp and Fraser MacBeth; Lincoln University and Shaun Wilson; Massey University is gratefully acknowledged. Funding for the project from the Ellett Agricultural Trust is also acknowledged.

\section{REFERENCES}

Bryant, A.M. 1984. Feed and management strategies at Ruakura. Proceedings Ruakura Farmers' Conference 36: 20-24.

Davie-Martin, C. 1989, Gain control over grazing. New Zealand Dairy Exporter, August: 15.

Glassey, C. 1983. Monitor your farm's pasture cover. New Zealand Dairy Exporter May: 11-13.

Hainsworth R.J.; Thomson, N.A. 1997. Identifying a feed surplus. Proceedings Ruakura Farmers' Conference 49: 100-105.

Hodgson, J. 1979. Nomenclature and definitions in grazing studies. Grass and forage science 34: 1118.

L'Huillier, P.J.; Thomson, N.A. 1988. Estimation of herbage mass in ryegrass-white clover dairy pastures. Proceedings of the New Zealand Grassland Association 49: 117-122.

Smeaton, D.C.; Winn, G.W. 1981. Assessment of standing dry matter on hill country by cutting to ground level. New Zealand journal of experimental agriculture 9: 263-269. 
